\title{
Voicing The Subaltern In AFrican-American AND Dalit Women's
} AUTOBIOGRAPHIES

\author{
ISABEL BELTRÁN
}

Universitat de València ibelma@alumni.uv.es

Received: 25-11-2020

Accepted: 01-02-2021

\begin{abstract}
This paper aims to analyse two major autobiographies of Dalit women's literature and African American women's writing - Karukku (1992) by Bama Faustina and Incidents in the Life of a Slave Girl (1861) by Harriet A. Jacobs - to bring forth the similarities between these two groups of subaltern women. Through the means of autobiography, both writers transmit their own experiences and denounce the gender, race and caste oppression endured. The subaltern theory coined by Antonio Gramsci and developed by Gayatri Spivak will be used to analyse these texts and the way they establish a link between two different worlds as well as how they share the common objective of making their narrators' exclusion visible in their patriarchal worlds.
\end{abstract}

KEYWORDS: Bama; Harriet A. Jacobs; Dalit; African American; caste system; slaver; subaltern

RESUMEN Dando voz al sujeto subalterno en las autobiografias de mujeres afroamericanas y dalit

Este artículo trata de analizar dos importantes autobiografías de la literatura de mujeres dalit y mujeres afroamericanas - Karukku de Bama Faustina (1992) e Incidents in the Life of a Slave Girl de Harriet A. Jacobs (1861) - con el fin de resaltar las similitudes entre estos dos grupos de mujeres subalternas. A través de la narración autobiográfica, estas escritoras transmiten sus propias experiencias y denuncian la opresión por género, raza y casta que sufren. La teoría del subalterno, acuñada por Antonio Gramsci y desarrollada por Gayatri Spivak, se utilizará para analizar estos textos y la manera en que establecen un vínculo entre dos mundos distintos y el objetivo común de hacer visible la exclusión de sus autoras en sus sociedades sometida al patriarcado.

PALABRAS CLAVE: Bama; Harriet A. Jacobs; dalit; afroamericano; sistema de casta; esclavitud; subalterno

In 1946, Bhimrao Ramji Ambedkar, the main activist in the Dalit -former Untouchables- movement and one of the principal drafters of the Indian post- 
independence constitution, wrote a letter to W.E.B. Du Bois, American civil rights activist and founder of the National Association for the Advancement of Coloured People (NAACP), where he justified his writing through the similarities between Untouchables in India and black people in America. Du Bois had filed a petition to the United Nations Organisation asking for accountability for human rights violations perpetrated against African Americans in the United States. Written in six chapters, his text covered areas from slavery and Jim Crow laws to education, employment, voting rights and access to health care. ${ }^{1}$ Ambedkar asked for a copy of this 96-page petition and informed $\mathrm{Du}$ Bois that Indian Untouchables wished to follow the example of African Americans. Du Bois's answer enclosed the petition by The National Negro Congress and promised to send a better developed one by the NAACP further on. He offered his sympathy and services to the Untouchable cause and Ambedkar. Although their correspondence ends here, the lines which trace the similarities from one cause to another were already being drawn.

This article analyses two autobiographical narratives written by two marginalized subjects: Karukku (1992) by Bama Faustina, a Tamil Dalit teacher and activist, and Incidents in the Life of a Slave Girl (1861) by Harriet Ann Jacobs, an African American slave. These two texts were written in different centuries, their authors, nevertheless, were the first to speak out and blatantly denounce the harassing conditions of life for Dalit women under the Indian caste system and black women in the American slavery system, and as such both narratives exemplify the evils of the discourses on race and caste, as well as gender. Moreover, while African American writing has been thoroughly analysed, Dalit literature has suffered a much narrower scope of recognition in ethnic literary studies. However, it is not only Dalit literature which has been disregarded. The social conflict of caste discrimination as a whole has been left aside when dealing with contemporary atrocities. While sexism, racism, xenophobia, class discrimination and other global evils are being tackled and challenged, the practice of the caste system in India has been relatively ignored. As much as casteism was illegalised after India's independence, the marginalization India's low caste subjects suffer claims urgent attention. Bama Faustina casts light on this issue highlighting the

\footnotetext{
${ }^{1}$ See https://www.aclu.org/blog/human-rights/human-rights-and-racial-justice/web-du-boiss-historic-unpetition-continues.
} 
injustices suffered by Dalit women in particular and Dalits in general. She leaves aside the individual in her autobiography to centre on her community and religion. On her part, Jacobs, a slave woman who escaped from the claws of the institution of slavery, became the first female slave to share her story with the American society on the brink of the American Civil War. The rarity of a former woman slave being able to read or write made her feat even more outstanding.

Thus, Karukku is the first autobiography written by a Tamil Dalit Catholic, Bama. Using this penname, the author tells the story of her tribulations as a young girl, her early education, her entering a convent and how she ended up leaving this Catholic institution due to the caste discrimination she suffered at the hands of the nuns. Together with her story she portrays those experiences of the people around her who were marginalized, beaten and even murdered for belonging to one of the lowest caste groups living in her village. Thus, her autobiography is not confined to her own person but it also includes the experiences of her community. Her being a Dalit marks her way throughout life and, even if the caste system had been abolished many years before her writing, its official banning made no difference in a society which was still influenced by archaic social and political structures.

Jacobs's Incidents is a transcending autobiographical narrative of a slave woman who suffered and fought her way to freedom. Jacobs made use of a pseudonym, Linda Brent, to describe her fight against the dehumanizing system of slavery. Her text is not only the first autobiography written by a fugitive black woman, but also one of the first to deal with controversial themes such as the sexual exploitation suffered by female slaves. The risk she took in escaping from her depraved master and his vindictive wife, the seven years she spent in hiding at her grandmother's home while peeping through a hole to see her children grow up, her flight up north and the passing of the Fugitive Slave Act which stopped her from assuming her freedom anywhere in the United States are some of the many difficulties she had to endure. 
I will interpret Bama's and Jacobs's narrators as subaltern characters and show how through the means of writing their autobiographical narratives, these two marginalised women authors denounce their silencing and aim to disengage from the subjection they were forced into by their societies.

\section{The Indian and the African American Subalterns}

Antonio Gramsci coined the term "subaltern" to refer to the groups of workers and peasants who were subject to the power and control of the hegemonic ruling classes. Under the Indian intellectual Ranajit Guha, the Subaltern Studies Group came together to apply this concept of subalternity to the field of South Asian studies. A series of volumes were published on this concept, the first one starting in 1982. Guha was inspired by his former teacher Susobhan Sarkar, a pioneer in discussing Gramsci's writings in India, and followed in his footsteps and tried to amend the traditional writing of history from the view of the dominant groups. His aim was to rewrite these histories "from below", and study them from the point of view of their colonial context.

In "Introduction: The Subaltern as Subaltern Citizen" to Subaltern Citizens and their Histories: Investigations from India and the USA (2009a), Gyanendra Pandey delves into the subaltern groups in capitalist, first-world societies such as the United States or India, one of Asia's most thriving democracies. Pandey exposes the evils which are counterpart to these rich nations and explains how there are invisible communities in these countries that remain silenced. As this scholar points out, in the case of the US, it is discordant how the constitution of the country, a symbol of freedom and liberty, was being written at the same time as the institution of slavery and Native American reservations were present. Even nowadays, there is no denying that the term subaltern can be applied to all those groups that are still subject to marginalisation, such as African Americans, Asian Americans, Latinos, the LGBTQ community, the poor, the disabled and even women in general. These are all groups who throughout history have had to fight and resist the hegemony of the white male upper classes, as well as their hegemonic representation as objects. Gayatri Spivak delineates their aims in her introduction, "Subaltern Studies: Deconstructing History", to Selected Subaltern Studies 
(1988). She denounces the methods of the elitist historiography and the necessity of its revision by intellectuals: "The historian must persist in his efforts in this awareness, that the subaltern is necessarily the absolute limit of the place where history is narrativized into logic" (Spivak, 1988: 16). As much as this awareness of the roles of the subaltern throughout history is needed, historians must not attempt to construct their discourses without engaging in a dialogue with the aforementioned subjects. Spivak ends by addressing the woman question and highlights the invisibility of women living in communities belonging to postcolonial societies such as India, and how they have been “drained of proper identity” (Spivak, 1988: 31).

Thus, it is in this context where I see the intersectional character that women from these communities evince. Even within the marginalised, the voiceless - particularly women - are subjected to the ever-present patriarchal hierarchy. They are the subalterns within the subalterns. Karukku and Incidents are both portrayals of the representation of the subaltern woman. Both women's narratives belong to subjected classes, Dalits and African Americans, and are examples of a subaltern consciousness that brings forth the view of the muted voices belonging to marginalised groups.

\section{India's Caste System and African Americans and Slavery}

While African-Americans were subjugated because of their skin colour, Dalits have been denied an identity through the dogmas of the Hindu religion. Yet, even if the source of discrimination is different, the connection between India's caste system and United States' racism is undeniable and can be traced back to the end of the $19^{\text {th }}$ century, when the first written account to express this relationship appeared. Jyotirao Phule, an Untouchable activist and anti-caste social reformer from Maharashtra, published his book Gulamgiri (Slavery) in 1873. Phule dedicated his work to those Americans who had fought to free slaves, linking the American abolitionist movement and the condition of black people in the United States to that of the lower castes in India. He wanted his country to emulate the African American fight for freedom and to 
raise awareness among the Dalit community to be rid of the oppression of the caste system. D. R. Ambedkar followed his example and had Phule in the highest esteem, considering him to be his guru. These two communities, worlds apart, were intrinsically connected as belonging to marginalized groups, silenced by the voice of the ruling class, and left aside as the voiceless, the subaltern.

In order to understand the Dalit struggle, we must go centuries back to understand the caste system. The word "Dalit" comes from Sanskrit and literally means "broken to pieces" and "suppressed". Dr. Babasaheb Ambedkar, ${ }^{2}$ the main figure in the Dalit fight against oppression, used this term to describe the people he aimed to defend, and he became the Dalit equivalent to Martin Luther King for African Americans. The difference underlying race and caste discrimination is that there is no racial basis for untouchability. While African-Americans were marginalized for their skin colour, Untouchables were oppressed and outside the caste system. ${ }^{3}$ Yet there are many similarities between this historical struggle of African Americans in the United States and the experience of Untouchables in India. Even though slavery was abolished more than a century and a half ago and the Civil Rights Movement put an end to a system of segregation, inequalities and discrimination are still fought through movements such as \#BlackLivesMatter.

\section{Subaltern Autobiographical Women Narratives}

The marginalisation of both Dalit and African American communities within their hegemonic societies encloses, however, further layers of internal oppression for Dalit and African American women due to the many discriminatory political, social and cultural practices against them because of their gender. For these women telling their

\footnotetext{
2 In 1927 B. R. Ambedkar's followers started to call him Babasahed, a Marathi phrase meaning "Respected Father" to show him their devotion.

3 Arundhati Roy explains the Indian caste system in her introduction to S. Anan's edition of The Annihilation of Caste (2014). She writes about how the caste system is not very different from the different social classes in modern day society. This discrimination is applied to women even more harshly. In Roy's words: "Men of the privileged castes had undisputed rights over the bodies of Untouchable women. Love is polluting. Rape is pure. In many parts of India, much of this continues to this day" (Roy, 2014: 15).
} 
stories with their own voices was and still is an undisputable way to rewrite and inscribe themselves as subjects in History.

Autobiographical narratives make it possible for authors to ascertain their own self. The controversy on how to distinguish actual facts from fiction in autobiographies as well as other disputed points including authorship, selfhood and representation led Philippe Lejeune to derive his definition for the genre as "retrospective prose narrative produced by a real person concerning his own existence, focusing on his individual life, in particular on the development of his personality" (qtd. in Anderson, 2001: 2). Lejeune also proposed the existence of an "autobiographical pact" which represents the will to honour the signature of the work. According to Lejeune, the author of an autobiography implicitly declares that he is the person he says he is and that the author and the protagonist are the same (qtd. in Anderson, 2001: 3). James Olney goes further and includes in his definition of the genre the act of justification implied in autobiographies, an essential point to take into account when analysing Jacobs's Incidents and Bama's Karukku (Olney, 1993: 212).

Linda Anderson goes on to address feminist texts and criticise the absence of them in comparison to canonical masculine autobiographies: "It was not that women did not produce autobiographical writing but that it was deemed to be unimportant, crude or illegitimate, to fail to live up to the necessary test of 'great writing"' (Anderson, 2001: 86). Departing from this innate discrimination, women's autobiographies have another fundamental characteristic which is to tell their story from a point of view which deviates from the hegemonic patriarchal discourse. It is imperative to recognise a division in women's and men's autobiographies in the same way as the subject in consideration will be different depending on other factors of marginalization. Subaltern women's narratives are more than autobiographies, since they enable women to denounce their situation, be heard through their writings and become empowered by deconstructing the dominant discourse. According to Julia Swindells, their memoirs reflect their tribulations and become a way of testimony as well as a call to action 
(Swindells, 1995: 7). Sidonie Smith uses the term "a negative position in culture" to classify the position from where subjugated people speak. This negative position is counterpart to the position of the Western white male who speaks from a point of political authority. It is therefore part of the work which surrounds the autobiographical genre to recoup members of these subaltern groups from their "negative position" (qtd. in Swindells, 1995: 5). Gender, race, caste, class and further aspects of marginalization cannot then be left unnoticed when analysing the autobiographical subject as it is within these aspects that the persona creates her story as well as that of her peers and community. For these subaltern voices, autobiography is a political strategy for liberation, a voice which speaks through the individual to reflect on the communal (Swindells, 1995: 6). The individual "I" in these autobiographies inevitably embeds a "we" that voices common problematics for the marginalized classes that the protagonist, author and narrator, represent.

Even though the identity that the marginalised Bama constructs is different from that presented by the slave Jacobs, there are parallels between the oppression suffered by both that my analysis points out. By comparing the various narrative strategies used by Jacobs in Incidents and by Bama in Karukku, I exemplify the similarities and points of convergence in both subaltern women's autobiographical texts.

Dalit life narratives started to come out in the years after Ambedkar's death as a literary response to the injustices they were suffering. ${ }^{4}$ It was in the late sixties and seventies that Untouchables took the name of Dalit and this vindicatory movement started to become empowered. Women's lack of education and their marginalisation within the Dalit community, where they were subjected to the domestic sphere and viewed as labour workers, is the main reason for their invisibility. Dalit women are the Dalits within the Dalit community, ${ }^{5}$ a fact that explains why Dalit women's narratives took a

\footnotetext{
${ }^{4}$ One of the earliest and most acclaimed texts, Untouchable by Mulk Raj Anand - who was not dalit himself - appeared in 1935 in English, and it narrates one day in the life of an Untouchable boy in a society dominated by the upper castes.

5 "Dalit feminists talked about the three-fold oppression of Dalit women as: 1-Dalits oppressed by upper castes; 2-Agricultural workers subject to class oppression, mainly at the hands of upper caste land owners; and 3-Women facing patriarchal oppression at the hands of all men, including men of their own castes" (Batliwala, 2008: 2).
} 
longer time to appear. It was not until 1995 that the National Federation of Dalit Women was formed and made Indian feminism address the caste issue.

From that moment onwards, Dalit women's voices started to be heard. Their narratives are a quite recent production which originated in Maharasthra. Bama's work Karukku is the first Dalit autobiographical woman's narrative. It was published in 1992 in Tamil and translated into English in 2000. Bama presents the reader with an autobiography that focuses more on her community than on her own life. She narrates her own experiences while at the same time telling the reader about events that happened when she was a young girl in her Parayar community. She reveals the discrimination from the upper castes towards the low castes, women being oppressed by both their own people and higher caste men, injustices carried out by the police on people in her community and how she suffered her fate as a Dalit within the Catholic community.

Bama's narrative deviates from the common linear chronological order of autobiographies, since the chapters in her narrative are organised consecutively but the years go backwards and forwards within each chapter. Moreover, the chapters are divided into the issues they dwell on such as education, caste and gender discrimination, the hypocrisy within the Catholic Church and the hardships Dalits from Bama's community, the Parayars, had to suffer. Her text is above all a criticism of India's caste system and of the atrocities Dalits have to undergo to survive in a casteist society. Karukku is written in colloquial Tamil in contrast to the standardised Tamil used by the educated, ${ }^{6}$ and thus, Bama's voice emphasizes the difference from the place she comes from to that of the upper classes and contests the oppressor's language. In the same way that she deviates from what be regarded as the standard autobiographical temporal narration, she also dwells deeply into the situation endured by her community in a typical Indian village in Tamil Nadu. Through her narrative Bama creates her identity and depicts it to the reader through stories of the caste oppression suffered not only by her but also by the Parayars. Bama shifts from the individual narrative to the collective

\footnotetext{
${ }^{6}$ According to Anushiya Sivanarayanan, "[t]he very form of language that Bama chooses to use - the colloquial, non-literary Tamil of the working classes - adds to its individuality" (135-136).
} 
biography where by telling the story of others she tells her own. The 'I' changes on several occasions to a 'we' when addressing the injustices:

Are Dalits not human beings? Do they not have common sense? Do they not have such attributes as a sense of honour and self-respect? Are they without any wisdom, beauty, dignity? What do we lack? They treat us in whatever way they choose, as if we are slaves who don't even possess human dignity. (Bama, 2012: 27)

As Pramod K. Nayar argues, the characteristics of Bama's narrative and other Dalit texts mean that Indian Dalit autobiography should be read as testimonio, a type of narrative generally associated with Latin American narratives, as "Dalit writings are narratives of trauma, pain, resistance, protest and social change. Dalit texts document the sufferings of and atrocities committed upon a large section of the population" (Nayar, 2006: 83). Bama's Karukku, and Jacobs's Incidents are both examples of testimonio narratives, adding gender as another layer of intersectionality.

In Incidents Jacobs presents Linda Brent as an independent, strong woman who fights for her and her children's freedom no matter what it costs. Joanne Braxton explains in Autobiography and African American Women's Literature the way black female writers deviated from the stereotyped norm and created their own self: "Defying every attempt to enslave them or diminish them or their self-expression in any way, black women autobiographers liberate themselves from stereotyped views of black womanhood, and define their own experiences" (128). This is precisely what Jacobs achieves through her narrative. She eschews conforming to conventions and presents to the public a narrative where she explains the way she deviates from social norms and her reasons for doing so. One fundamental attribute of nineteenth-century true womanhood was the possession of sexual purity (Carby, 1987: 61), a fact that Jacobs denies as she presents herself as a black woman engaged in a non-marital relationship with a white man, Mr. Sands, from the beginning of her narrative. As Hazel Carby explains, "[i]n contrast to the expected pattern of a confessional passage, which called for the unconditional acceptance of the readers, Linda Brent's act of sexual defiance was described as one of 'deliberate calculation"' (Carby, 1987: 74). However, this form of representation was the cause for some historians, such as John Blassingame in The Slave Community (1972), to insist on the inauthenticity of Harriet Jacobs's narrative. Blassingame 
condemned the text to the realms of the melodramatic genre, and affirmed that because Jacobs's narrative does not conform to the guidelines of representativeness, it was an inauthentic text (qtd. Carby, 1987: 63). Hazel V. Carby reproaches his criteria and states that it is possible to make an analogy between Blassingame's accusation of Incidents as part of the melodrama genre and "the frequency with which issues of miscegenation, unrequited love, outraged virtue, and planter licentiousness are found foregrounded in diaries by Southern white women, while absent or in the background of the records of their planter husbands" (Carby, 1987: 64). For Carby this difference can be considered to be a characteristic of women's narratives compared to men's writings. Carby concludes that Blassingame's dismissal of Jacobs's text and his refusal to acknowledge its credibility are ideologically based, since what Jacobs is offering is a "uniquely female perspective" (Carby, 1987: 64).

Hence, Bama's and Jacobs's autobiographies present very different structures, languages and times. Bama uses a colloquial Tamil that is appreciated in Lakshmi Holmström's translation. She leaves aside a chronological order in her autobiography, and divides chapters according to different issues, and the events which take place in her narrative are contemporary. On the other hand, Jacobs follows a chronological order, and writes in a formal English in order to assert the authenticity of her narrative and reach an audience of free women who would listen and react to her plight. Her narrative is situated in the antebellum period of the United States, even though it still bears a deep resonance for twenty-first century America. They shape their narratives with authenticity through the way they address their readers, the narrative structure, language used and above all, their resistance to take a passive stand. Their narratives become representative of voiceless women who struggle to be heard but are relentless in their will to speak out. Their voicelessness comes from their position as subalterns in societies which marginalize them but through their writings they confirm their position as people who are willing to fight and confront a reality that keeps undermining them. Bama's and Jacobs's narratives, even if written in far-away countries and far apart 
centuries, hold in their essence similar struggles and show their protagonists' desire to become agents of change for women of their race and caste.

\section{Caste and Race Oppression}

Bama's Karukku describes the caste oppression suffered within a Dalit community in the Tamil Nadu region in India. Her narrative is a representation of Dalit women's awareness and the consciousness of a Dalit community as well as a story of disillusionment. While narrating her story, Bama intermingles it with events which occurred in her village and through a non-chronological narration speaks about her society's reality. Cosimo Zene returns to Gramsci in order to apply his subaltern theory, which he deems indispensable, to the issue of Dalits in South Asia and asks again Spivak's notorious question: Can the subaltern speak? His proposal takes Spivak's views further forward:

If a young woman belonging to a high-caste kills herself without explanation and that gesture is interpreted as the "silence of the subaltern", my reply is that Dalit women are doubly subaltern, both as women and as Dalit. Not only does the Dalit woman speak and talk, but she wants to be listened to through words, poetry, singing, dancing and working- and more precisely the always underpaid extra-work (Zene, 2020: 88-89)

This is precisely what we find in Karukku. Bama writes her autobiography to heal her internal wounds (Bama, 2012: ix) but manages in the act to represent a community that is suffering like her. According to N. M. Aston, untouchability was "a kind of socioreligious slavery imposed upon the Dalit people. It got institutionalized over the centuries in social norms, customs and traditions" (Aston, 2001: 19). Although caste discrimination had been prohibited before Bama was born, children were still experiencing this marginalisation perpetuated through customs and traditions. Bama felt this discrimination from the very beginning of her life, even though there was not a name put to it in her early years it was ubiquitous in her every day experiences (Bama, 2012: 13). Bama was born into a poor low-caste family where her brother became her guide while she became conscious of the injustices Dalits like her suffered. Thus he explained that, "[b]ecause we are born into the Paraya jati, we are never given any honour or dignity or respect. We are stripped of all that. But if we study and make progress we can throw away these indignities." (Bama, 2012: 18) His advice became 
central throughout her life as she succeeded in school which enabled her to carry on studying rather than limit herself to the agricultural work her family did for a living.

Bama belonged to the caste of the Parayas. Alongside them in the community there were other castes belonging to the lowest of the varnas, such as the Nadars, Koravar, Pallas and the Chaaliyar. The latter were constantly suffering confrontations with the Parayas in violent intercaste incidents. Bama explains how the upper caste communities were separated from the lower-caste ones in different parts of the village, each group keeping to their own area (Bama, 2012: 7). The Naicker caste had all of the essential stores and commodities in their area, even a school which was meant only for the upper caste children and therefore they had no need to go into areas populated by what they viewed as polluted people. Sriti Ganguly delves into this aspect arguing that:

segregation along caste lines is largely assumed to be a feature of the rural. However, studies indicate that a similar spatial organisation is reproduced in urban centres as well, where large populations, particularly those of poor Dalits, continue to inhabit segregated settlements, even in metropolitan cities. (Ganguly, 2018: 52)

It was at the convent where Bama started working after attaining the Bachelor of Education, that she experienced the true meaning of caste discrimination. When she entered the convent she hid her Dalit identity in order not to be marginalised and lists some of the beliefs and things people there said about Dalits: they should know their place and not enter the homes of people from other castes, nothing should be done for them, their nature is as it is, they can be camouflaged if they wear the same clothes as other people and they believed the government gave them too many privileges which were not required by illiterate people (Bama, 2012: 115). Bama withstood these accusations while working with them until she could endure it no longer and left. She denounces not only the people who restrain Dalits from advancing, who marginalise them and humiliate them, but also those Dalits who accept a passive position and do nothing to change the order of things (Bama, 2012: 80). As Nayar claims, Dalit writing "reveals the structure of the traumatic experience while also gesturing at the ways in which the victims have fought, overcome and survived the event. Dalit life-writing is about the re-construction of the self after the traumatic event" (Nayar, 2006: 84). 
As for Jacobs's narrative, the issue of race discrimination is ubiquitous in the shaping of her text. Jacobs's first sentence in her narrative, "I was born a slave; but I never knew it till six years of happy childhood had passed away" (Jacobs, 1987: 5), thus stating who she is from the very beginning. The early six year period of innocence soon faded with her mother's death and reality struck with the realization that she was considered a piece of property rather than a human being. But Jacobs's character soon surfaces along with her resilience and contempt towards the institution of slavery. Mirroring the attitude of her brothers William and Benjamin she shuns a passive stance and positions herself as a militant in the fight for freedom. Her attacks on passivity are not limited to her own attitude but she makes sure to address them to her white audience, blaming northern passivity for not acting on these injustices: "In view of these things, why are ye silent, ye free men and women of the north? Why do your tongues falter in maintenance of the right?" (Jacobs, 1987: 29). She uses this confessional narrative strategy on several occasions, especially when explaining herself to her audience presenting her sexual history (Jacobs, 1987: xxi), but also to invite them to take action in order to overturn the slavery system (Jacobs, 1987: 35-36).

In chapter XII, "Fear of Insurrection", Jacobs goes into the events that took place after Nat Turner's insurrection broke out in 1831 and which gave people's racism an excuse to unfold throughout the country (Jacobs, 1987: 63). The retaliation against coloured people was the perfect excuse for poor whites to find a scapegoat for their miseries, without stopping to consider that the oppression and marginalization slaves were subjected to were also inflicted on them by society's upper classes. In a further passage in the narrative, when Jacobs talks about her visit to England, she speaks about the poverty of Europe and how they "lived in the most primitive manner" but she still believed "that the most ignorant and the most destitute of these peasants was a thousand fold better off than the most pampered American slave" (Jacobs, 1987: 184) as they were not controlled by masters or overseers. Moreover, Jacobs's flight to the North in order to escape the horrors of slavery brings on a further disillusionment as she discovers that the picture of the North as a sanctuary for runaway slaves was far from reality (Jacobs, 1987: 162-163). 
Both Dalits and African Americans are undoubtedly the subaltern voices in the societies they inhabit. Bama and Jacobs take an active stand within their societies and call for action to overturn the hegemonic control of their oppressors. They criticise passivity and disdain their peers who accept the established order and consent to their own illtreatment. Bama's decision to leave the convent where she worked for its ill-treatment of Dalits and Jacobs's fight to escape the institution of slavery and confront race discrimination portray these women's active roles in their stand against caste and race oppression. Their narratives have become the voice through which they denounce the injustices perpetuated by the society they live in and the means through which their stories are spread.

As Joanne M. Braxton defines it, Jacobs's ultimate triumph is her backtalking narrative, "In many cases, autobiographies become the black woman's letters of liberation, addressed first to herself, then to the community that surrounds and supports her, and, finally, to the hostile outside world" (Braxton, 2010: 131). Jacobs defined her own experience in a different structure of autobiography to Bama's, nevertheless their goals are linked. Bama's unconventional narrative places her work as one of the major Dalit autobiographies, a narrative created through a sense of necessity and responsibility. In her words "I write because I think it is the duty and responsibility to write the stories of my people. I also feel that by writing my own wounds are healed and I am liberated and renewed" (Bama, 2018: 4).

\section{Gender Oppression}

Bama faces in Karukku the triple discrimination of belonging to the lower castes, lower class and being a woman. She argues how Dalit feminism is different from feminism in India as the problems faced by Dalit women are entirely different to those non-Dalit women face (Bama, 2018: 5). In the same way as Bama criticizes Indian feminism, Sharmila Rege, an Indian sociologist and feminist scholar, criticises the "reluctance on part of white feminists to confront the challenges posed to them by black and third 
world feminism", and adds that "[i]n the framework of postorientalism studies, the focus remains on colonial domination alone, thereby the pre-colonial roots of caste, gender, and class domination come to be ignored" (Rege, 1998: 39). Dalit women's voices carried on to be muted through the latest social movements of the twentieth century such as the Dalit Panthers where "Dalit women remained encapsulated firmly in the roles of the 'mother' and the 'victimised sexual being'" (Rege, 1998: 42). ${ }^{7}$

Bama highlights how women manage to survive on their own when men have to go into hiding because of the incidents with the Pallar men (Bama, 2012: 38). This distinction elucidates the fact that women were seen as incapable of carrying on without the men's earnings. Their agency as men's saviours brings forth a newfound respect which they had not been granted before, denoting how they were undervalued and undermined (Bama, 2012: 43). This was projected in their wages, as "Even if they did the same work, men received one wage, women another. They always paid men more" (Bama, 2012: 54-55). Bama's ingenuity as a small child makes her wonder about this difference in the earnings depending on the person's gender.

Shailaja Paik addresses the marginalisation of these women in her article "Building Bridges: Articulating Dalit and African American Women's Solidarity" (2014), and explains that they were subjugated not only in the public sphere but also in the domestic space. Although Bama does not allude to any gender violence suffered by herself, one of the stories she tells about her village people is about a man called Uudan, the Tamil name for "blower". He was known all through the village for dragging his wife every day to the community hall where he would proceed to beat her with his belt. However, no one reacted to this, no one would try to stop it, even though "Everyone came to watch" (Bama, 2012: 61). The torture his wife was submitted to was treated as a social event where people gathered to watch her suffering without reacting to the violence being inflicted. This lack of reaction to violent events towards women proved how women could be seen as commodities, property of their men and only to be dealt with accordingly.

\footnotetext{
${ }^{7}$ For a study of the Liberation Panthers Party (Viduthalai Chiruthaigal Katchi), the group representing Dalits in Tamil Nadu and their impact on the social and political structures, see Hugo Gorringe's Panthers in Parliament: Dalits, Caste, and Political Power in South India (2017).
} 
Bama also addresses the question of marriage and exposes her priorities, putting education before married life. Towards the end of the narrative she delves into this issue, questioning whether it is worthwhile marrying only to combat economic problems and loneliness (Bama, 2012: 131). She defies the oppressive power marriage has on Dalit women as it usually is their sole means of survival. She courageously resists marrying and subjecting herself to a domineering male companion only because of loneliness and economic pressure, therefore breaking with her society's conventions in order to seek a life which she could dedicate to her community rather than to a single male presence. The true combative nature of her narrative is upheld through her faithfulness to her beliefs. Neha Arora delves into this issue and how Bama goads women for their emancipation, questioning

Why should women accept the words of men as laws, as scriptures, as rules? Why should their lives centre around their husbands? [...] Bama's views on marriage are quite revolutionary. The idea of marriage and respectability/chastity being interrelated is unintelligible to her (Arora, 2007: 9).

For her part, Jacobs, as a slave woman, also faces the triple oppression of class, race and gender. Incidents portrays the sexual exploitation of its protagonist at her master's hands, deconstructs the notions of true womanhood prevalent in the nineteenth century, and redefines the concept of motherhood. Adrienne D. Davis argues how feminist studies have shed light on the ways that slavery's sexual and racial subordination converged around the bodies of enslaved black women (Davis, 2003: 457). In fact, Jacobs addresses free white women to defend herself and her actions and reveals how principles of morality cannot be applied in the same manner to bonded women, "[b]ut, O, ye happy women, whose purity has been sheltered from childhood, who have been free to choose the objects of your affection, whose homes are protected by law, do not judge the poor desolate slave girl too severely!" (Jacobs, 1987: 54). Yet Jacobs draws an image of herself as an active agent which confronts the traditional portrayal of slave women as victims in most male slave narratives (Becker, 1992: 413). She rejects the "tragic mulatto" trope and vouches for action. Her seven years in her grandmother's attic, rather than portray "the mad woman in the attic" represent a woman who patiently 
awaits her opportunity to escape, turning the attic into a militant space where Jacobs plans her next moves (Manuel, 1998: 40). Her rebelliousness is also viewed through her approach to motherhood. Jacobs is above all presented as a mother. Sarah W. Sherman dismisses the centrality of purity and its loss in the narrative and places "motherhood" as the main principle and experience of morality to which Jacobs adheres (Sherman, 1990: 174).

Bama's and Jacobs's voices represent those subaltern subjects speaking from the margins. As Leema Rose explains:

the issues agitating women belonging to different cultures are different. The differences between the political priorities of the first and third-world women have persisted to the present, although the interconnection of various forms of social oppression materially affects the lives of all women (Rose, 2014: 801).

This interconnectedness is viewed when analysing Bama's and Jacobs's voices. While Bama separates herself from Indian feminism, Jacobs's narrative becomes a piece of work which substantiates the black feminist position where the role of the African American slave woman is validated as equal to that of the free white American woman who she speaks to in an effort to arouse a feeling of sisterhood. Both Bama and Jacobs address the violence suffered by women in the domestic sphere and in the working spaces (convent and master's house) at the hands of licentious masters and hostile nuns, and delve into the role of marriage and sexuality in their lives as oppressive systems. Bama refuses to subject her life to the sole purpose of marrying and be put under the control of a man in order to be useful to her community and Jacobs declares herself the sole owner of her sexuality and uses it to keep her master away from her. She does this by initiating a liaison with a unmarried white man who becomes the father of her children, transgressing the notion of "true womanhood" and defying its application to women who lived under the yoke of slavery. Through these actions the protagonists of Karukku and Incidents in the Life of a Slave Girl show how they become active agents and embrace their gender fight against a patriarchal society which oppresses them not only for their caste and race but for their condition as women.

\section{Conclusion}

My analysis of Bama's Karakku and Jacobs's Incidents has aimed to establish a link between the subjection of African American slave women and Dalit women. Both 
authors reject their position as undermined subjects and reach out to their counterparts to condemn their lack of freedom and equality. Both narratives portray two different realities set in different parts of the world, yet, there are unavoidable similarities between their oppression in societies that view them as inferior to their white and upper caste counterparts, and at the same time further marginalize them for their gender. The autobiographies of these two women set a precedent in both their societies, each taking an active stand against the injustices suffered in their countries and advocating for change and progress. This fight is still being carried out by subaltern women who like these two authors are relentless in their fight. Through their autobiographies, Bama and Jacobs depict the power of the printed word and establish a precedent for the change that their communities aim to achieve.

\section{WORKS CITED}

AMBEDKAR, B. R. (2014). Annihilation of Caste. London: Verso.

ANDERSON, LINDA (2001). Autobiography, New York: Routledge.

ARORA, NEHA (2007). "Bama's Women: The Wrinkled Faces or The Balls Bouncing Back?”, Scholar Critic Vol. 4, No2, August: 1-14.

ASTON, N. M. (2001). "Introduction”, In: N. M. Aston (ed). Literature of Marginality: Dalit Literature and African American Literature, New Delhi: Prestige: 1-20.

BAMA (2012). Karukku. 1992. Translation by Lakshmi Holmstöm, Oxford: Oxford University Press.

BAMA (2018). "Dalit Feminist Activist Writes Back: Bama Faustina in Conversation with Jaydeep Sarangi", Writers in Conversation, Vol. 5, No1, February: 1-8.

BATLIWALA, SRILATHA (2008). Changing Their World Concepts and Practices of Women's Movements, New Delhi: Brijbasi Art Press.

BECKER, ELIZABETH C. (1992). "Harriet Jacobs's Search for Home”, CLA Journal, Vol. 35, No4: 411-421.

BLASSINGAME, JOHN (1972). The Slave Community. Oxford: Oxford University Press. 
BRAXTON, JOANNE M. (2010). “Autobiography and African American Women's Literature", In: Angelyn Mitchell \& Danille K. Taylor (eds). The Cambridge Companion to African American Women's Literature, Cambridge: Cambridge University Press: 128-149.

CARBY, HAZEL V. (1987). Reconstructing Womanhood: The Emergence of the AfroAmerican Woman Novelist, New York, Oxford: Oxford University Press.

DAVIS, ADRIENNE D. (2003). "Slavery and the Roots of Sexual Harassment", In: Catharine MacKinnon \& Reva B. Siegel (eds). Directions in Sexual Harassment, New Haven, Connecticut: Yale University Press: 457-478.

GANGULY, SRITI (2018). "Social Construction of a Segregated Urban Space and Its Effects on Education: A Case Study of the Balmikis of Delhi", Contemporary Education Dialogue, Vol. 15, №1: 51-72.

GORRINGE, HUGO (2017). Panthers in Parliament: Dalits, Caste, and Political Power in South India. Oxford: Oxford University Press. https://doi.org/10.1093/acprof:oso/9780199468157.001.0001

GUHA, RANAJIT (1988). "Preface", In: Ranajit Guha \& Gayatri Chakravorty Spivak (eds). Selected Subaltern Studies, Oxford: Oxford University Press: 35-36.

JACOBS, HARRIET A. (1987). Incidents in the Life of a Slave Girl. Jean Fagan Yellin (ed). Belknap Press: Harvard University Press.

MANUEL, CARME (1998). "Women but not Sisters: Harriet A. Jacobs's Angered Literary Reply to Harriet B. Stowe", Revista de Estudios Norteamericanos, Vol. 6: $35-50$.

NAYAR, PRAMOD K. (2006). "Bama's Karukku: Dalit Autobiography as Testimonio", The Journal of Commonwealth Literature, Vol. 41, №2: 83-100. https://doi.org/10.1177/0021989406065773

OLNEY, JAMES (1993). "The Value of Autobiography for Comparative Studies. African versus Western Autobiography", In: William L. Andrews (ed). African American Autobiography: A Collection of Critical Essays, Englewood Cliffs, N.J.: Prentice Hall: 212-223.

PAIK, SHAILAJA (2014). "Building Bridges: Articulating Dalit and African American Women's Solidarity", WSQ: Women's Studies Quarterly, Vol. 42, No3-4 Fall/Winter: 74-96.

PANDEY, GYANENDRA (2009a). "Introduction: The Subaltern as Subaltern Citizen", In: Gyanendra Pandey (ed). Subaltern Citizens and their Histories: Investigations from India and the USA, New York: Routledge: 1-12.

REGE, SHARMILA (1998). "Dalit Women Talk Differently", Economic and Political Weekly, Vol. 33, Nº44, October-November: 39-46. 
ROSE, LEEMA (2014). "Indian Subaltern Feminism and American Black Womanism”. 13 April, 9th International Academic Conference, Istanbul. https://ideas.repec.org/p/sek/iacpro/0100872.html

ROY, ARUNDHATI (2014). "Introduction: The Doctor and the Saint". In: B. R. Ambedkar. Annihilation of Caste, London: Verso: 17-179.

SHERMAN, SARAH W. (1990). "Moral Experience in Harriet Jacobs's Incidents in the Life of a Slave Girl", NWSA Journal, Vol. 2, No2, Spring: 167-185.

SIVANARAYANAN, ANUSHIYA (2009). "Translation and Globalization: Tamil Dalit Literature and Bama's Karukku”, In: Nalini Iyer \& Bonnie Zare (eds). Other Tongues Rethinking the Language Debates in India Amsterdam, New York: Rodopi: 135-154.

SPIVAK, GAYATRI CHAKRAVORTY (1988). "Introduction. Subaltern Studies: Deconstructing History”, In: Ranajit Guha \& Gayatri Chakravorty Spiva (eds). Selected Subaltern Studies, Oxford: Oxford University Press: 3-32.

SWINDELLS, JULIA (1995). "Introduction", In: Julia Swindells (ed). The Uses of Autobiography. London, New York: Routledge: 1-12.

ZENE, COSIMO (2020). "Self-consciousness of the Dalits as 'Subalterns': Reflections on Gramsci in South Asia", Reflections on Gramsci in South Asia: Rethinking Marxism: A Journal of Economics, Culture \& Society, Vol. 23, №1: 83-99.

Isabel Beltrán Manuel holds a B.A. in English Studies from the Universitat de València (Spain). Her Final Degree Dissertation "Voicing the Subaltern in AfricanAmerican and Dalit Women Autobiographies" (supervised by Dr. Ma José Coperías) won the AEEII 1st Research Award in Interdisciplinary India Studies (2020). She is currently studying a Master's Degree in Secondary Education Teaching at the University of València. 